\title{
Openness, exchange rate regimes and the Phillips curve
}

\author{
Christopher Bowdler \\ Nuffield College \\ University of Oxford \\ Contact address: Christopher Bowdler, Nuffield College, Oxford, OX1 1NF, UK \\ Phone: +44 1865278508 \\ Fax: +44 1865278621 \\ Email: christopher.bowdler@nuf.ox.ac.uk
}

\begin{abstract}
A number of theoretical models predict that the slope of the Phillips curve increases with trade openness, but cross-country studies provide little evidence for such a correlation. We highlight two reasons for this finding. Firstly, the strength of the relationship may depend on the extent of exchange rate adjustment, which is a potential determinant of output and inflation dynamics in open economies, but previous studies have not made a distinction between fixed and floating exchange rate regimes. Secondly, existing estimates of the Phillips curve slope are based on data from the 1950s through the 1980s, and are therefore likely affected by price and wage controls, inflationary oil price hikes and the role played by fiscal policy in driving output and inflation (the underlying theory requires that monetary shocks dominate). We calculate new measures of the Phillips curve slope using data from 1981-98, a period during which these factors were arguably less important. Regressions based on the new measures indicate that the Phillips curve slope increases with trade openness amongst countries maintaining flexible and semi-flexible exchange rate regimes, but is unrelated to openness amongst countries maintaining fixed exchange rate regimes.
\end{abstract}

Keywords: Openness, inflation, Phillips curve, sacrifice ratio, exchange rate regime. JEL Classification: E31, E32, F41. 


\section{Introduction}

This paper investigates the hypothesis that the slope of the short-run Phillips curve (the amount of inflation associated with a unit increase in output) is positively related to trade openness. Such a relationship is suggested by open economy models incorporating short-run price stickiness, for example Romer (1993) and Guender and McCaw (2000), but finds very little support in the existing empirical literature, see Ball, Mankiw and Romer (1988), Ball (1994) and Temple (2002). We argue for two important extensions of previous research. The first is to allow the relationship between openness and the Phillips curve slope to depend on the exchange rate regime and the second is to focus on measures of the Phillips curve slope obtained using data for the 1980s and 1990s.

The motivation for the first extension derives from the underlying theory. Open economy models of the Phillips curve often assume that unanticipated increases in the money supply lead to depreciation of the nominal and real exchange rates. This pushes up the relative price of imports, raising inflation and restricting the increase in output associated with monetary expansion. These effects will be stronger in more open economies and therefore the slope of the Phillips curve will be an increasing function of openness. To the extent that the exchange rate is in practice an important determinant of output and inflation adjustment, any positive correlation between openness and the Phillips curve slope is likely stronger amongst countries that follow flexible exchange rate policies. ${ }^{1}$ In order to allow for this possibility the regression models that we estimate control for an interaction between openness and the exchange rate regime, the latter being measured using the de facto classifications reported by Reinhart and Rogoff (2004).

The second innovation relates to the measurement of the slope of the Phillips curve. Most existing research uses the output-inflation trade-offs reported by Ball, Mankiw and Romer (1988) and the sacrifice ratios calculated by Ball (1994). The sample periods used to calculate these indices vary slightly across countries, the earliest data being from the late 1940s and the latest from the mid 1980s. In this paper we calculate new versions of these statistics for the period

\footnotetext{
${ }^{1}$ A relationship between openness and the Phillips curve slope is still possible when the exchange rate is fixed. The point here is that it is likely to be less strong than if the exchange rate were flexible.
} 
1981 - 98. There are several reasons for expecting a stronger correlation between openness and the Phillips curve slope during the post-1980 period. Firstly, the underlying theory requires that monetary policy is the main driver of short-run output and inflation movements, but prior to the 1980s fiscal policy played an important role in cyclical fluctuations and this may have undermined the link between openness and the Phillips curve. Secondly, price controls were more common before 1980 and these may have limited the impact of exchange rates on domestic prices, again weakening the relationship between openness and the Phillips curve slope.

Our results show that if the Phillips curve slope is measured using data through the mid1980s the findings are very similar to those of Temple (2002), in that the slope of the Phillips curve appears to be unrelated to trade openness, even amongst countries that followed the most flexible exchange rate policies. The picture changes when the regressions are estimated using post-1980 data. The slope of the Phillips curve then increases with openness and the relationship is stronger the more flexible the exchange rate. This is consistent with the findings of Hau (2002) who shows that within a sample of developing and industrial countries the variance of the real exchange rate over the period $1980-98$ is negatively related to openness (the explanation is that faster price adjustment in open economies cancels out the effects of the nominal exchange rate on the real exchange rate, such that real exchange rate volatility decreases).

The relationships that we document are robust to adding further controls and to omitting outlying observations, although the statistical significance of the results varies across model specifications. The influence of the exchange rate regime appears more important when the Phillips curve slope is measured using the output-inflation trade-off than when it is measured using the sacrifice ratio, possibly because the two indices measure the relationship between output and inflation over different time horizons.

The rest of the paper expands on these points and is structured as follows. Section 2 reviews the theoretical literature on openness and the Phillips curve. Section 3 describes the empirical framework to be used and deals with important issues such as the measurement of the Phillips curve slope, trade openness and the exchange rate regime. Sections 4 and 5 present results based on the methods for measuring the Phillips curve slope suggested in Ball, Mankiw and Romer (1988) and Ball (1994) respectively. Section 6 concludes with a summary of the main arguments. 


\section{Open economy models of the Phillips curve}

The link between openness and the slope of the Phillips curve is analysed in Romer (1993), who builds on an earlier contribution by Rogoff (1985). In this model prices are sticky for a fixed proportion of domestically produced goods, while the price of imported goods is equal to the exogenous foreign price multiplied by the nominal exchange rate. If there is an unanticipated increase in the money supply the real exchange rate will depreciate and this will affect the Phillips curve for two reasons. Firstly, some imports contribute to the domestic price level directly and as these goods increase in price following a depreciation the rate of inflation will rise. ${ }^{2}$ Secondly, if wages are indexed to the general price level, or if imported materials are used in domestic production, firms will increase output by less for a given increase in the money supply because higher costs make production less profitable. In more open economies both effects will be stronger, a point emphasised by Karras (1999), who shows empirically that inflation is more responsive to money supply shocks and output less responsive to money supply shocks the greater is trade openness. If the slope of the Phillips curve is measured as the derivative of inflation with respect to output (relative to trend) it will be positively related to openness.

As noted by Temple (2002) the argument requires a systematic link between monetary shocks and the real exchange rate. In Romer's model it is assumed that domestic and foreign goods are imperfect substitutes and that each country can influence the world price of goods through its production decisions. A monetary expansion raises domestic output relative to foreign output and consequently the relative price of domestic goods falls, i.e. there is a real depreciation. Lane (1997) argues that the assumption that each country can affect world prices is unrealistic, particularly if trade patterns are highly diversified. An alternative approach is the monetary theory of the exchange rate used in the models of Dornbusch (1976), Frankel and Chinn (1995)

\footnotetext{
${ }^{2}$ This argument assumes that there is some pass-through from exchange rate fluctuations to both import prices and consumer prices. Empirical studies typically find partial pass-through to import prices and limited, though still statistically significant, pass-through to final prices, see for example McCarthy (1999). It is important to note that the argument presented here requires pass-through to consumer prices following monetary shocks. Pass-through following exchange rate fluctuations that are unrelated to monetary policy may still be incomplete, and it could be these episodes that dominate the results from empirical studies that document very low rates of pass-through to final prices.
} 
and Guender and McCaw (2000) amongst others. In such models the nominal exchange rate (domestic currency units per foreign currency unit) equals the domestic money supply minus domestic output, plus a random shock (all variables in logs). As some domestic prices are sticky in the short-run, an unexpected increase in the money supply will depreciate the exchange rate more quickly than it increases the average price level, such that the real exchange rate falls.

The empirical evidence suggests some support for a link between monetary policy and the exchange rate. Obstfeld and Rogoff (1996, pp. 621-22) note that the Volcker deflation that took place in the United States during the early 1980s and the Thatcher-Howe deflation that occurred in the United Kingdom at the same time were both associated with appreciations of the nominal and real exchange rates. Faust and Rogers (2003) show that structural expansions in monetary policy in the United States induce depreciation of the US dollar against the British pound and the Deutsche Mark, though they also note that monetary policy is not the dominant source of exchange rate volatility amongst these countries.

The exchange rate adjustment required for a correlation between openness and the slope of the Phillips curve will occur less often in countries that fix the exchange rate. In the polar case of a completely fixed exchange rate and full capital mobility domestic monetary policy must always be set in line with foreign monetary policy, see Shambaugh (2004) for some supporting evidence. If policy were not to be set in this way an interest rate differential would emerge between the home economy and the rest of the world and the fixed exchange rate would be untenable. In this setting movements along the short-run Phillips curve can still occur, e.g. due to the effects of fiscal policy or the world business cycle, but if the nominal exchange rate is fixed these fluctuations may be less highly correlated with increases in the relative price of imports and consequently the link between the Phillips curve slope and openness will be less strong.

It is important to note, of course, that fixing the exchange rate affects just one of the channels through which openness may influence the Phillips curve slope, and that a correlation between these two variables could arise through other channels. If, for example, the short-run supply curve for imports is more inelastic than that for domestically produced goods, e.g. because there is a time lag in increasing the quantity of imports, then the positive relationship will still hold. The point to be emphasised here is simply that we expect the relationship between openness and 
the slope of the Phillips curve to be less strong under fixed exchange rates than under flexible exchange rates.

A final point to note is that some recent theoretical contributions suggest that openness decreases the slope of the Phillips curve. In Razin and Yuen (2002) increased openness is associated with fewer borrowing constraints and greater consumption smoothing. This reduces the incentive for workers to decrease real wage demands following negative monetary shocks, which in turn reduces the incentive for firms to cut prices. Consequently inflation is less responsive to output in more open economies, i.e. the Phillips curve is less steep. Daniels and VanHoose (2003) reach a similar conclusion using a model based on imperfect competition in product and labour markets. In this framework greater openness reduces the income elasticity of spending on domestic goods and therefore weakens the incentive for firms to raise prices following an output expansion.

These models abstract from the import price effects emphasised in Romer (1993) and Guender and McCaw (2000). Therefore in practice the relationship between openness and the slope of the Phillips curve will depend on whether the effects of the exchange rate on consumer prices and output dominate the microeconomic effects discussed in Razin and Yuen (2002) and Daniels and VanHoose (2003). The results to be presented in this paper support the view that openness increases the slope of the Phillips curve, especially under flexible exchange rate conditions. This does not rule out the mechanisms emphasised in more recent contributions, but does suggest that during the post-1980 period their effects have been less strong than those operating through the exchange rate.

\section{Testing models of the Phillips curve}

The empirical relationship between openness and the slope of the Phillips curve is briefly examined in Ball, Mankiw and Romer (1988) and Ball (1994). Neither study finds any evidence that openness increases the slope of the Phillips curve. Temple (2002) reaches a similar conclusion in a more detailed study that controls for other macroeconomic variables and for the effects of outlying observations. The regressions estimated in these studies are of the form 


$$
P C_{i}=\text { const }+\beta * O P E N_{i}+\lambda^{\prime} \mathbf{X}
$$

where $i$ denotes a country, $P C$ the slope of the Phillips curve, $O P E N$ the share of imports in GDP and $\mathbf{X}$ a set of additional controls. In order to allow the impact of openness on the slope of the Phillips curve to be larger in countries that follow flexible exchange rate policies we define $E X$ as an indicator of the exchange rate regime that increases with exchange rate flexibility and has a zero mean across $i$. An extended regression model can then be written as

$$
P C_{i}=\text { const }+\beta O P E N_{i}+\gamma O P E N_{i} * E X_{i}+\lambda^{\prime} \mathbf{X}
$$

In equation (2) the $\beta$ parameter measures the effect of openness on the Phillips curve slope amongst countries that maintain an "average" amount of exchange rate flexibility. The $\gamma$ parameter captures the change in the impact of openness that occurs as the flexibility of the exchange rate increases. Equation (2) therefore allows for the possibility that the relationship between openness and the Phillips curve slope is stronger amongst flexible exchange rate countries. It should be noted that the interaction term may affect the estimate of $\beta$. If $O P E N$ and $E X$ are negatively correlated, e.g. because relatively open economies are more likely to maintain fixed exchange rates (Edwards (1996)), omitting the interaction term could bias the $\beta$ parameter towards zero.

Measuring the Phillips curve slope Following Temple (2002) we look at two separate measures of the slope of the Phillips curve, the output-inflation trade-offs of Ball, Mankiw and Romer (1988), hereafter BMR, and the sacrifice ratios of Ball (1994). ${ }^{3}$ The first of these is discussed here and the second is discussed in section 5. BMR measure the slope of the Phillips curve by estimating the responsiveness of output to inflation. This is given by the $\pi$ coefficient in the regression

$$
y_{t}=\text { const }+\pi \Delta x_{t}+\lambda y_{t-1}+\gamma t
$$

The log of real GDP in year $t, y_{t}$, is regressed on a constant, its own lag, a time trend and the change in the log of nominal GDP, $\Delta x_{t}$. The $\pi$ coefficient indicates the proportion of a shock

\footnotetext{
${ }^{3}$ Temple also considers a third measure due to Jordan (1997), but in less detail than the other two measures.
} 
to nominal GDP that shows up in output within the same year. An estimate of $\pi$ close to unity implies that real and nominal GDP are highly correlated and that price movements account for very little short-run nominal income variation. This suggests that the Phillips curve is shallow in output-inflation space. In contrast, an estimate close to zero suggests that the Phillips curve is steep, since inflation rather than output is the main driver of nominal GDP. Hence, the $\pi$ parameter is negatively related to the slope of the Phillips curve.

BMR compute $\pi$ for 43 countries using time series running from the late 1940s to the mid 1980s, though varying by country. Additionally, the sample is split at the end of 1972 and separate $\pi$ coefficients are estimated for each sub-sample. A key contribution of this paper is to consider not only these measures of the Phillips curve slope but also new estimates based on the period $1981-98 .{ }^{4}$ These use data from the International Financial Statistics database, the source referenced by BMR.

There are several reasons for considering updated measures of the slope of the Phillips curve. Firstly, the theoretical models discussed in section 2 predict a correlation between openness and the slope of the Phillips curve on the assumption that macroeconomic fluctuations are the result of monetary shocks that induce exchange rate adjustment. During the first half of the post-war period, however, governments often used fiscal policy to manage demand (see Nelson (2003) for a discussion of the British case) and such policy interventions need not induce the same exchange rate adjustment as monetary shocks. In contrast, since 1980 fiscal policy has played a less important role in short-run fluctuations. One reason for this is that fiscal policy discretion has been curbed by formal legal restrictions such as the balanced budget requirements introduced in the United States and the stability and growth pact adopted by European countries preparing for monetary union. Fatas and Mihov (2004) discuss the restrictions that have been imposed on discretionary fiscal policy since the 1980s.

Secondly, price controls were commonplace prior to 1980, for example they were implemented in the United States by the Nixon administration and in the United Kingdom by the Heath administration. ${ }^{5}$ Such restrictions may have limited the impact of the exchange rate on inflation

\footnotetext{
${ }^{4}$ The sample ends in 1998 because after this year many European countries adopted a single currency, which complicates the measurement of trade openness in the cross-country regressions.

${ }^{5}$ Nielsen and Bowdler (2005) show that price and wage adjustment in the United Kingdom was affected by the
} 
and thereby weakened the relationship between openness and the slope of the Phillips curve. Since 1980 state regulation of price-setting has been less important, partly as a result of the privatisation of many state controlled industries, and such a change makes a relationship between openness and the Phillips curve slope more likely during the post-1980 period.

Thirdly, the 1970s saw two large surges in oil prices, which increased inflation and decreased output relative to trend. These may have distorted the measurement of the Phillips curve slope. BMR acknowledge this point but argue that it does not affect their findings concerning average inflation and the slope of the Phillips curve. In principle the problem could be addressed through estimating equations that control for supply-side influences on inflation, see Bowdler (2003), but the data required for such an exercise are not available for a large sample of countries. Instead, measuring the Phillips curve slope using post-1980 data is a simple way of trying to reduce the effects of measurement bias, since data commencing in 1981 are less likely to be affected by large supply shocks. This provides a second reason for considering updated measures of the Phillips curve slope. ${ }^{6}$

The new measures of the slope of the Phillips curve are calculated for 41 countries and are tabulated in the appendix. The correlation between these measures and the full sample BMR estimates is $51 \%$, indicating that the pattern of international differences in the slope of the Phillips curve has changed over time. ${ }^{7}$ The main differences between the two sets of estimates often occur for countries for which the earlier measure is very close to zero. For example, the largest discrepancies occur for the UK and Austria, and for each of these countries the BMR statistic for the period $1948-86$ is -0.020 (the estimates that we obtain for the post1980 period are 1.039 and 0.753 respectively). One explanation for these differences is that the earlier estimates reflect the importance of supply shocks, which typically induce a negative correlation between output and inflation and therefore bias the $\pi$ coefficient towards zero. ${ }^{8}$ price controls imposed during the 1970s.

${ }^{6}$ The post-1980 period includes the 1986 oil price collapse, but the macroeconomic effects of oil price reductions are known to be smaller than those of oil price increases, see Muellbauer and Nunziata (2004).

${ }^{7}$ Data revisions could account for some of the differences. If we compute the BMR statistic using our data for the period 1973 - 86 the correlation with the series that BMR compute for $1973-86$ is over $90 \%$, suggesting that data revisions are unlikely to be the main reason for the differences between the BMR full sample statistics and those that we obtain for $1981-98$.

${ }^{8}$ It is interesting to note that Froyen and Waud (1995) question the accuracy of BMR's estimate of the slope 
This may explain why the average value of the earlier estimates, at 0.238 , is less than that of the later estimates, which is 0.312 . It should be noted, however, that the post-1980 readings do include some negative numbers, indicating that whilst these estimates may provide a more accurate description of cross-country differences in the slope of the Phillips curve, an element of measurement bias remains.

Measuring trade openness Trade openness is measured as the share of imported goods and services in domestic GDP, an approach that is standard in the literature, see Romer (1993) and Temple (2002). The figure for each country is an average over the period of time for which the slope of the Phillips curve is measured and is recorded as a decimal, i.e. $30 \%$ openness is 0.3 .

Measures of the exchange rate regime The main exchange rate regime classification considered in this paper is that due to Reinhart and Rogoff (2004). This index is available at the annual frequency and varies from 1 to 5 , where higher values denote greater exchange rate flexibility. The classification has two important characteristics. Firstly, it is a de facto classification based on the volatility of the actual exchange rate. This is important because the theoretical discussion in section 2 suggests that actual exchange rate flexibility matters for the determination of the Phillips curve slope, not the regime that policy authorities claim to be maintaining (Romer (1993) argues that a de jure exchange rate regime classification may be of little relevance in explaining the openness-inflation relationship). Secondly, where relevant, the classification uses parallel exchange rate data in addition to official exchange rate data. The former refers to the price at which currency is traded in transactions that do not involve the central bank. Reinhart and Rogoff note that the parallel rate is a good leading indicator for the official rate and best captures foreign exchange market conditions. As it is the average rate at which currency is actually traded that determines import prices and the slope of the Phillips curve, the Reinhart-Rogoff index is a suitable exchange rate classification for the analysis to be carried out in this paper. ${ }^{9}$

of the Phillips curve for Austria.

${ }^{9}$ The classification is based on a country's exchange rate against a major trading partner rather than a trade weighted exchange rate, which would be preferable. The problem should not be too important, however, because the number of base countries is quite small, which means that when a country depreciates against its largest 
An observation for $E X_{i}$ in equation (2) is obtained by first taking the average of the ReinhartRogoff index for country $i$ over the period for which $P C_{i}$ is measured. This gives a cross-country exchange rate regime classification that is converted to zero mean form through subtracting the sample average from each observation. The demeaned variable is then used in the regression analysis. It is important to note that using time averages of the Reinhart-Rogoff index means combining information from separate exchange rate regimes in some instances, and we address the implications of this in section $4 .^{10}$

The exchange rate regime classification due to Shambaugh (2004) is also considered in some of the regression estimates in order to check the robustness of the basic results. This is a $0-1$ de facto classification that uses different criteria in assessing actual exchange rate behaviour and does not look at parallel market data. As such it is closer to the de jure classification reported by the IMF (the correlation between the Shambaugh and IMF measures is $83 \%$ in our sample of countries, whilst the correlation between the IMF and Reinhart-Rogoff measures is $59 \%) .{ }^{11}$

\section{Empirical results}

In the first column of Table 1 the dependent variable is the BMR parameter measured for the period $1948-86$. The controls (in addition to openness) are the level and square of average annual inflation and the level and square of the standard deviation of annual nominal GDP growth, each calculated for the period used to estimate equation (3). BMR argue that these variables affect the Phillips curve through their impact on the frequency of price adjustment. Our data for openness do not go back to the 1940s, so as in Temple (2002) the openness statistics

trading partner it is also likely to be depreciating against other large trading partners.

${ }^{10}$ We also computed $E X_{i}$ for a version of the Reinhart-Rogoff scheme defined over the range $1-4$, where the level 4 category is obtained through merging the level 4 and level 5 outcomes from the original classification. Level 4 in the original Reinhart-Rogoff scheme refers to flexible exchange rates, while level 5 refers to currencies that are flexibly priced and judged to be in crisis ('freely falling'). The rationale for combining these two categories is that an $E X$ variable that assigns a relatively high score to freely falling currencies may be too sensitive to these rare events. The qualitative implications of the results that we report in section 4 are robust to constructing $E X$ from an exchange rate classification defined over the range $1-4$.

${ }^{11}$ A further classification is provided by Levy-Yeyati and Sturzenegger (2003), but is only available for two thirds of the countries that we consider. 
used in columns (1) and (2) are those from Romer (1993), which are averages for the period $1973-88 .{ }^{12}$ The appendix lists the 41 countries included in the full sample and notes some minor differences between this sample and that used by Temple (2002). Estimation is by OLS and t-ratios are presented in parentheses. ${ }^{13}$ The latter are based on heteroscedasticity consistent standard errors that allow for the possibility that the Phillips curve proxy is more accurate for some countries than for others. The standard errors are not adjusted to take account of the uncertainty associated with the derived dependent variable, but remain valid when calculating t-ratios for the null of no effect, see Pagan (1984). ${ }^{14}$

The results confirm the main findings from past research: Openness does not exert a significant effect on the slope of the Phillips curve and the point estimate is of opposite sign to that predicted by Romer (the coefficient on $O P E N$ should be negative if openness leads to steeper Phillips curves). Column 2 adds the interaction $O P E N * E X$, but this term is also insignificant. In columns 3 and 4 all of the variables are measured over the period 1973 - 86 (the dependent variable is based on our calculations). The coefficients for $O P E N$ and $O P E N * E X$ are negatively signed, but are insignificant in most cases and adding further controls does not change this picture (results not reported).

In columns 5-10 the variables are measured using data for 1981-98. A simple regression in which $O P E N$ is the only control produces results similar to those obtained previously. The picture changes in column 6, however. Allowing the relationship between openness and the slope of the Phillips curve to depend on the exchange rate regime leads to a negative coefficient on openness and this is significant at the $15 \%$ level, indicating some evidence that openness is associated with steeper Phillips curves amongst countries that allow an intermediate degree of exchange rate flexibility. Amongst countries for which the exchange rate regime indicator is one standard deviation above the mean, the effective coefficient for openness is -1.10 , which is significant at the $1 \%$ level, whilst amongst countries for which the exchange rate regime indicator

\footnotetext{
${ }^{12}$ There is only partial overlap with the 1948 - 86 period used to measure the dependent variable, but this will be of little consequence given that between country variation in openness dominates within country variation in openness.

${ }^{13}$ All of the regressions reported in this paper use the PcGIVE software of Doornik and Hendry (2001).

${ }^{14}$ All of the regressions reported in this paper were obtained using the PcGIVE software of Doornik and Hendry (2001).
} 
is one standard deviation below the mean, the effective coefficient is .10, which is insignificant at all conventional levels. Hence, the column 6 results indicate a strong correlation between openness and the Phillips curve slope amongst flexible exchange rate countries, a weaker and less significant relationship amongst countries maintaining intermediate exchange rate flexibility, and no relationship between openness and the Phillips curve slope amongst countries maintaining fixed exchange rates.

It is interesting to focus on the changes in the results that occur across columns 5 and 6 on controlling for the interaction term. As $O P E N$ and $E X$ are negatively correlated in the sample, a regression that does not include the interaction term indicates a weak correlation between openness and the Phillips curve amongst countries that maintain intermediate exchange rate flexibility, in addition to leaving out the very strong relationship between openness and the Phillips curve slope amongst flexible exchange rate countries.

The remaining columns add further variables. Controlling for mean inflation (column 7) yields an openness coefficient for the 'average' country (in terms of exchange rate flexibility) that is significant at the $5 \%$ level, though including the square of mean inflation in column 8 weakens the results. Adding the volatility terms leaves the results essentially unchanged, but we do not attach great importance to these regressions given that the point estimate for VOL is of opposite sign to that predicted by theory (Lucas (1973) argued that greater nominal uncertainty should increase the slope of the Phillips curve, in which case the coefficient for $V O L$ should be negative). One explanation for this finding is that $V O L$ is a poor measure of nominal uncertainty.

What of the quantitative significance of the results? Using the column 7 estimates, the increase in the slope of the Phillips curve associated with a one standard deviation increase in openness is 0.62 standard deviations of the dependent variable if exchange rate flexibility is one standard deviation above the mean, 0.41 standard deviations of the dependent variable if exchange rate flexibility is at the mean, and 0.20 standard deviations of the dependent variable if exchange rate flexibility is one standard deviation below the mean. These effects are somewhat smaller if calculated using the results from the other columns, but still suggest that openness may account for an important component of international variation in the slope of the Phillips 
curve, especially if the exchange rate is free to float.

\section{Table 1 - see end of document.}

\subsection{Sensitivity and robustness}

Yuen (2001) argues that the exchange rate regime affects the slope of the Phillips curve directly. If this is the case the effect of $O P E N * E X$ could be spurious in the sense that it depends on excluding the level of $E X$ from the regressions. Adding $E X$ to specifications $6-10$ in Table 1 leads to very small increases in the absolute t-ratios for $O P E N$ and very small decreases in those for $O P E N * E X$, while the $E X$ term itself is not robustly significant (results are available on request). Thus, the findings do not depend on excluding the level of $E X$ from the regressions.

Checking for outlying observations The second issue that we address is whether or not the results are dependent on outliers. In order to do this we regress $P C$ on $O P E N * E X$ and collect the residuals, $P C 1^{*}$. Then we regress $O P E N$ on $O P E N * E X$ and collect the residuals, $O P E N 1^{*}$, and then we plot $P C 1^{*}$ against $O P E N 1^{*}$ in the top left graph in Figure 1. This is the projection of the regression plane from column 6 in Table 1 into $O P E N-P C$ space. The graph in the top right box in Figure 1 is the projection of the same regression into $O P E N * E X-P C$ space. The second and third rows contain analogous plots for regressions 8 and 10 from Table 1 (only the projections into $O P E N-P C$ and $O P E N * E X-P C$ space are reported). If outliers drive the results, these observations will be easy to detect in scatter plots for the transformed variables.

In each of the plots the data points occur at regular intervals and the lines of best fit do not appear to be dependent on specific observations. One possible exception occurs in respect of the observation lying furthest east in each of the six panels, which is that for Israel. Regressions estimated for a sample that excludes Israel are reported in the first two rows of Table 2 . The relationship between openness, the exchange rate regime and the slope of the Phillips curve is generally robust, and is actually somewhat stronger in the case of the regression that controls for inflation and its square. 
In the third and fourth rows of Table 2 the regressions are estimated using samples that exclude Argentina, Bolivia and Brazil. Although these countries do not appear as conditional outliers in Figure 1, their average inflation rates far exceed the sample average and could be exerting undue influence. The results are weaker in the more general of the two models, mainly because the exclusion of these countries leads to an increase in the significance of the inflation regressors, which then reduces the partial correlation between the Phillips curve slope and terms in openness.

Identifying individual exchange rate regimes The next question that we address is whether or not the results are affected by the fact that the 1981 - 98 period often sees changes in the Reinhart-Rogoff index, e.g. a country could be classified as 1 (completely fixed exchange rate) for $1981-89$ and 2 (limited exchange rate flexibility) for $1990-98$. Such changes could lead to time variation in the Phillips curve slope. In order to address this issue we identify for each country the longest interval from the post-1980 period for which just one of the 5 categories in the Reinhart-Rogoff scheme is applicable. The slope of the Phillips curve and each of the regressors are calculated for the period for which an unchanged exchange rate regime applies and the cross-country regressions re-estimated using the new data. The results are summarised in the fifth and sixth rows of Table 2. The coefficients on $O P E N$ and $O P E N * E X$ are significant at the $5 \%$ level in each specification and therefore provide somewhat stronger evidence for a link between openness and the Phillips curve than did the baseline results. The point estimates and standard errors for the openness terms are larger than in Table 1, possibly reflecting greater estimation uncertainty when shorter periods are used to compute the observations for each country.

Using an alternative measure of the exchange rate regime The last two regressions in Table 2 use the exchange rate classification due to Shambaugh (2004). The results are much weaker than those based on the Reinhart-Rogoff scheme. In the specification that does not control for inflation and its square the expected relationship between openness and the Phillips curve slope is significant only amongst countries that maintain greatest exchange rate flexibility. In the more general regression both coefficients on terms in openness are insignificant 
at conventional levels, though they are both of the expected sign. One explanation for these findings is that the binary classification entails a loss of information compared to the multi-tier Reinhart-Rogoff scheme. Also, given that the alternative index does not include information from parallel currency markets it may be considered a less comprehensive guide to the history of the exchange rate regime.

Figure 1 - see end of document.

Table 2 - see end of document.

Controlling for reverse causation Next we investigate the possibility that the results are due to reverse causation. Consider a country that faces a steep Phillips curves for reasons unrelated to openness and the exchange rate regime. Demand shocks will induce relatively volatile inflation and a relatively volatile exchange rate in such a country, causing it to be placed towards the flexible end of the Reinhart-Rogoff classification. This could lead to a spurious relationship between openness, the exchange rate regime and the slope of the Phillips curve. Two-stage least squares (2SLS) estimation can be used to address this issue.

In column 1 of Table $3 E X$ is treated as endogenous and $O P E N$ is treated as exogenous. The first stage regression for $O P E N * E X$ uses as instruments the levels and squares of the exogenous term, $O P E N$, and land area in square miles (data for the latter are taken from Romer (1993)). The outside instrument is used on the grounds that small countries may be more dependent on trade with the rest of the world and may therefore be inclined to select a fixed exchange rate regime. A Hansen J-test indicates that the null hypothesis of instrument validity cannot be rejected at the $10 \%$ level (this test is based on the sample analogue of the over-identifying moment conditions that underpin the 2SLS estimator and is robust to heteroscedasticity in the residuals). It is also important to note that the F-statistic for the first stage regression is 11.18 and significant at the $0.1 \%$ level, confirming that the instruments have adequate explanatory power for the endogenous regressor (Stock, Wright and Yogo (2002) suggest that an F-statistic greater than 10 is sufficient to ensure that weak instrument biases are avoided). As in the case of the OLS estimates the $t$-ratios calculated from the second stage regression use heteroscedasticity 
consistent standard errors. ${ }^{15}$

The coefficient estimates for $O P E N$ and $O P E N * E X$ are negative and larger in absolute size than those obtained by OLS (see Table 1, column 6), though due to the additional estimation uncertainty neither term is individually significant at the $5 \%$ level. This outcome changes in column 2, however, in which the level and square of inflation are used as regressors and are treated as potentially endogenous. The level and square of per capita income in 1980 US $\$$ are added to the instrument set in order to handle the additional endogenous regressors (data are from Romer (1993)). The slope coefficients for the openness term and its interaction with the exchange rate regime are each significant at the $5 \%$ level, as are those for the terms in inflation. All of the coefficients change somewhat relative to the OLS case, however, see column 8 in Table 1. Overall, the results from 2SLS estimation indicate that the relationship between openness, the exchange rate regime and the Phillips curve is unlikely the result of reverse causation bias.

\section{Table 3 - see end of document.}

\section{Evidence from sacrifice ratios}

This section uses sacrifice ratios to measure the slope of the Phillips curve, as in Temple (2002). This is defined by Ball (1994) as the ratio between total output losses and the change in trend inflation over the course of a disinflation (a disinflation is a period during which trend inflation falls by more than 1.5 percentage points from peak to trough). Total output losses are calculated as the sum of annual deviations of real GDP from a straight line connecting output in the year of an inflation peak to output in the year after an inflation trough. Trend inflation in year $t$ is an average of the annual rate of consumer price inflation recorded in eight quarters, namely the four quarters of year $t$, the last two quarters of $t-1$ and the first two quarters of $t+1$. Ball calculates sacrifice ratios for 65 disinflation episodes in 19 OECD countries observed for $1961-91$.

A small sacrifice ratio corresponds to a steep Phillips curve and so again we expect negative

\footnotetext{
${ }^{15}$ All of the 2SLS estimates are obtained using the ivreg2 package in STATA 9.0. This package also allows for Generalised Method of Moments (GMM) estimation, and we found that this method delivered very similar results to those reported in Table 3.
} 
coefficients for openness and its interaction with the exchange rate regime. In column 1 of Table 4 the dependent variable is the set of sacrifice ratios reported by Ball and the explanatory variables are as follows:

- $O P E N$ is the measure of openness used by Temple (2002), i.e. an average for $1973-88$.

- $E X$ is the average of the Reinhart-Rogoff index over the course of the disinflation.

- $L E N G T H$ is the disinflation length in years.

- INFLOSS is the reduction in inflation during the disinflation.

- $P E A K$ is the inflation rate in the year in which the disinflation started.

The last three controls are used by Ball (1994) and Temple (2002). ${ }^{16}$ As in Temple (2002) the results indicate little support for the hypothesis that openness increases the Phillips curves slope. One reason for this may be that many of the sacrifice ratios correspond to disinflations from the 1960s and 1970s and are drawn entirely from OECD countries. In order to investigate this idea we calculated sacrifice ratios for disinflations occurring during the post-1980 period in the sample of countries considered in section 4 (disinflations starting before 1980 but which lie mainly in the post-1980 period are included in the sample). In a few cases disinflations started from extremely high inflation rates of more than 100\%, mainly in Latin American countries during the 1980s. These episodes were excluded from the analysis leaving a sample of 71 sacrifice ratios drawn from 38 countries (this is a subset of the 41 country sample used in section 4 because some countries did not implement any disinflations). The data are tabulated in the appendix. ${ }^{17} \mathrm{It}$ should be noted that less than $30 \%$ of the sacrifice ratios that we calculate are for disinflations spanning the negative shock to oil prices in 1986. This is important because it suggests that the new information that we collect regarding the slope of the Phillips curve mainly relates to the dynamics of output and inflation following a demand contraction rather than the effects of a supply shock.

The disinflations that we identify for the 19 countries considered by Ball do not always

\footnotetext{
${ }^{16} \mathrm{~A}$ measure of the duration of wage contracts is also used by these authors. We do not consider this variable because it is not available for the larger sample of countries included in regressions $2-6$. In any case, the variable is not significant at the $5 \%$ level in the regressions reported by Temple.

${ }^{17}$ In the case of Germany we use Ball's measure of the sacrifice ratio for 1980 - 86 due to problems in obtaining consistent data for inflation spanning German unification in 1991.
} 
match those reported by Ball. For Japan, the Netherlands, Sweden, Switzerland and the UK, Ball identifies two disinflations during the early 1980s, whereas we identify just one. This is due to data revisions that have smoothed out some turning points. The correlation between the two sets of sacrifice ratios calculated for the other 14 countries studied by Ball is $87.5 \%$, indicating agreement over the pattern of international differences in the slope of the Phillips curve in most cases. $^{18}$

Columns 2-6 report regressions for the new sample of sacrifice ratios (explanatory variables are measured over periods covered by the corresponding disinflations). In column 2 there is some evidence that openness increases the slope of the Phillips curve even though the exchange rate regime interaction is excluded. The relationship is not significant at the $5 \%$ level, however. In column 3 the interaction between openness and the exchange rate regime is added and both terms are significant at the $5 \%$ level. ${ }^{19}$ If this specification is re-estimated using only the 19 countries considered by Ball and Temple (giving a sample of 38 observations) the coefficient for openness is $-6.57(t=-1.94)$ and that for the interaction is $-2.80(t=-1.63)$ indicating that the magnitude of the relationship between openness and the sacrifice ratio does not depend on including non-OECD countries in the sample. Instead, it appears that the relationship between openness, the Phillips curve slope and the exchange rate regime depends on using data from the post-1980 period. This is consistent with the findings of the previous section, in which the output-inflation trade-off was used to measure the slope of the Phillips curve.

It is interesting to note that the coefficient on the interaction term in column 2 is approximately one third the size of that on openness, whereas in the output-inflation trade-off regressions the two effects were of similar magnitude. Further, in regressions $4-6$ in Table 4 the interaction term becomes insignificant, most likely because the length and scale of a disinflation are channels through which openness and exchange rate adjustment influence the slope of the Phillips curve.

A possible reason for the exchange rate regime being less important in inducing a correlation

\footnotetext{
${ }^{18}$ Bernanke et al. (1999) and Boschen and Weise (2001) compute sacrifice ratios using more recent vintages of data than Ball (1994) and also note small differences in the exact dates for disinflation episodes and the magnitudes of the sacrifice ratios when compared to those in Ball (1994).

${ }^{19}$ The coefficient for openness increases substantially when using sacrifice ratios from the post-1980 period. This reflects the fact that sacrifice ratios have generally been larger during that period due to disinflations having been smaller in magnitude during the last quarter of a century.
} 
between openness and the sacrifice ratio than in inducing a correlation between openness and the output-inflation trade-off is that the former measures the relationship between output and inflation over a longer horizon than does the latter. For example, the mean duration of the 71 disinflation episodes is 4.2 years, whereas the output-inflation trade-off focuses on a 1 year horizon. Over the medium-term a correlation between openness and the Phillips curve slope may be more likely, e.g. because the pass-through from exchange rate movements to import and consumer prices increases with time. As a result, when the Phillips curve is measured over a four year horizon it is related to openness even amongst countries that allow only an intermediate degree of exchange rate flexibility because even medium sized exchange rate movements lead to some price adjustment. In contrast, when the Phillips curve is measured over a one year horizon it is only relatively large exchange rate movements that induce inflation adjustment, such that openness exerts a statistically significant effect only amongst those countries that allow greatest exchange rate flexibility. ${ }^{20}$

Table 4 -see end of document.

Checking for outliers In order to check for outlying observations we plotted the conditional relationships between the sacrifice ratio, openness and the interaction between openness and the exchange rate regime. The scatter graphs (not reported here) revealed the following outlying observations:

- Finland, 1989 - 96. This episode includes the Russian crisis of the early 1990s, which caused Finnish GDP to collapse. Consequently the sacrifice ratio is almost 10 times the sample average.

- Panama, 1980 - 86. Panama has the highest level of openness in the sample and therefore appears as an outlier.

In Table 5 we summarise the results obtained for regressions that include dummy variables for these observations. The relationship between openness, the exchange rate regime and the

\footnotetext{
${ }^{20}$ An alternative explanation for the sacrifice ratio being more closely related to openness is that (unlike BMR's output-inflation tradeoff) it derives from an inflation measure based on consumer prices rather than the GDP deflator. Consumer prices include import prices directly and as a result their dynamics are more likely to be closely related to the openness of the economy.
} 
slope of the Phillips curve is preserved, though note that the coefficients for openness and the interaction term are slightly smaller than those reported previously.

Table 5 - see end of document.

Controlling for reverse causation bias In column 1 of Table 6 we treat $O P E N * E X$ as endogenous and estimate a 2SLS regression in which the additional instruments are the levels and squares of land area and income in 1980. The relationship between openness, the exchange rate regime and the slope of the Phillips curve is robust, though as in section 4 the point estimates are larger than those obtained by OLS. The Hansen test associated with this regression yields a $p$ value of $49 \%$ and the first stage regression an F-statistic of 11.47 , indicating that the instruments are valid and explain a non-trivial proportion of the variation in the endogenous variable. The picture is essentially the same in column 2, in which the square of openness is added to the instrument set to provide a comparison with the instrument set used to obtain the results in Table 3. Overall, the evidence from sacrifice ratios appears more robust to 2SLS estimation than that from output-inflation tradeoffs. ${ }^{21}$

Table 6 - see end of document.

The role of central bank independence The final issue that we address is whether or not the results are robust to controlling for measures of central bank independence, $C B I$. Daniels et al. (2004) show that when $C B I$ and its interaction with openness are added to the sacrifice ratio regressions in Temple (2002), the slope of the Phillips curve is found to be a decreasing function of openness, the opposite result to that predicted in Romer (1993). This finding is based on the Ball (1994) estimates of the sacrifice ratio. In Table 7 we ask whether or not a similar result holds for the sacrifice ratios that we have calculated. The $C B I$ variable is measured using Cukierman's (1992) index of the legal independence of central banks. This is just one of the indices considered in Daniels et al. (2004), though similar results are obtained for each measure

\footnotetext{
${ }^{21}$ We do not consider regressions that add further controls because the instruments available for terms such as LENGTH are very weak, leading to results in which all regressors are insignificant at the $5 \%$ level (although of the same sign as those reported in our main results).
} 
of $C B I$. As the index is available for only a subset of the 38 countries included in Table 4 the sample size falls from 71 to 53 .

Regressions $1-5$ in Table 7 add $C B I$ and $O P E N * C B I$ to the main specifications in Table 4. These variables are not significant at any stage. In each case the coefficients on openness and the exchange rate interaction term are negative, though they are less significant than before. ${ }^{22}$ Similar results obtain when the sample is further restricted through considering disinflations occurring only in the 19 countries considered by Ball, but these are not reported here.

One interpretation of these findings and those in Daniels et al. (2004) is the following. For much of the period considered by Ball (1994) the mechanisms that might cause the slope of the Phillips curve to increase with openness did not operate because government control of pricing decisions and macroeconomic management based largely on fiscal policy prevented the necessary exchange rate and price adjustment. Consequently factors causing the Phillips curve slope to respond negatively to openness dominated, hence the Daniels et al. findings. In contrast, for the sample that we consider monetary policy has been more important in driving economic fluctuations and this has lead to the exchange rate and price adjustment that causes the Phillips curve slope to increase with openness, hence the findings in this paper. Thus, we do not interpret our results as being at odds with those in Daniels et al., but rather as a sign that the mechanisms underpinning the Phillips curve relationship have changed through time.

\section{Table 7 - see end of document.}

\section{Summary}

This paper has examined the hypothesis that the slope of the Phillips curve is positively related to trade openness. Such a relationship arises in standard open economy models incorporating short-run price stickiness. The paper focuses on two extensions of existing empirical research on this topic. Firstly, the strength of the relationship is allowed to depend on the exchange rate regime. Secondly, the Phillips curve slope is measured using data from only the 1980s and 1990s. Evidence from both output-inflation trade-offs and sacrifice ratios indicates that

\footnotetext{
${ }^{22}$ The sample mean for $C B I$ is 0.36 , so even though the $O P E N * C B I$ term is positively signed, the derivative of the sacrifice ratio with respect to openness remains negative for almost all countries.
} 
amongst countries maintaining flexible exchange rate regimes the effect of openness has been to increase the Phillips curve slope, though this relationship has only been evident during the post-1980 period. One explanation for this finding is that during the past quarter of a century macroeconomic management has relied less heavily on fiscal policy and price controls, both of which are likely to undermine a relationship between openness and the Phillips curve slope. In extensions of the basic econometric approach the results showed some fragility, but the overall picture indicates stronger support for the underlying theory than has previous research in this area, and it seems that a positive effect of openness on the slope of the Phillips curve cannot be ruled out.

\section{Acknowledgements}

Financial assistance from a British Academy post-doctoral fellowship is gratefully acknowledged. This paper extends work reported in Nuffield College working paper 2003-04. I have benefited from many helpful discussions with John Muellbauer and Jon Temple on the topics addressed in these two papers, and special thanks are due to both of them. I also thank John Bluedorn, Rui Fernandes, Roland Meeks, Heino Bohn Nielsen, Adrian Pagan, Phurichai Rungcharoenkitkul, Kamakshya Trivedi and seminar participants in Oxford and at the 2003 Money, Macro and Finance conference in Cambridge, UK, for helpful comments on the previous paper on this topic. Any remaining flaws are my responsibility. 


\section{Appendix}

This appendix lists output-inflation trade-offs and sacrifice ratios for the post-1980 period. South Africa and Zaire are excluded from the sample used by Temple (2002) because the exchange rate regime indicator is missing for these countries in some or all years, but New Zealand is added, giving 41 countries in total. This is the sample used in all regressions in Tables 1-3, except those in columns 3 and 4 in Table 1. Brazil, Nicaragua and Peru drop out of the sample in these cases due to gaps in the data used to estimate the slope of the Phillips curve for $1973-86$. In column 1 in Table 1 the observation for New Zealand is taken from Froyen and Waud (1995), who follow the same methodology as BMR. The samples used in Tables 4-7 are described in the text. 


\section{References}

Ball, Laurence, N. Gregory Mankiw and David Romer (1988). "The New Keynesian Economics and the Output-Inflation Tradeoff." Brookings Papers on Economic Activity, 1, 1-65.

Ball, Laurence (1994). "What determines the sacrifice ratio?" In Mankiw, N. G. ed. Monetary Policy, pp. 155-182. University of Chicago Press, Chicago.

Bernanke, Ben, Thomas Laubach, Frederic Mishkin and Adam Posen (1999). Inflation Targeting: Lessons from the International Experience. Princeton University Press.

Boschen, John and Charles Weise (2001). "The Ex Ante Credibility of Disinflation Policy and the Cost of Reducing Inflation." Journal of Macroeconomics, 23, 323-47.

Bowdler, Christopher (2003). "Openness and the output-inflation tradeoff." Nuffield college working papers in economics, no. 03-04.

Cukierman, Alex (1992). Central bank strategy, credibility and independence: theory and evidence. The MIT Press, Cambridge MA.

Daniels, Joseph and David VanHoose (2003). "Openness, the Sacrifice Ratio, and Inflation: Is there a Puzzle?" Unpublished manuscript, Baylor University and Marquette University.

Daniels, Joseph, Farrokh Nourzad and David VanHoose (2004). "Openness, central bank independence and the sacrifice ratio." Journal of Money, Credit and Banking, forthcoming.

Dornbusch, Rudiger (1976). "Expectations and exchange rate dynamics." Journal of Political Economy, 84, 1161-1176.

Edwards, Sebastian (1996). "The Determinants of the Choice between Fixed and Flexible Exchange Rate Regimes.” NBER Working Paper 5756.

Fatas, Antonio and Ilian Mihov (2004). "Fiscal discipline, volatility and growth." Mimeo, INSEAD, France.

Faust, Jon and John Rogers (2003). "Monetary policy's role in exchange rate behavior." Journal of Monetary Economics, 50, 1403-1424.

Frankel, Jeffrey and Menzie Chinn (1995). "The Stabilizing Properties of a Nominal GNP Rule." Journal of Money, Credit and Banking, 27, 318-334.

Froyen, Richard and Roger Waud (1995). "Central Bank Independence and the OutputInflation Tradeoff." Journal of Economics and Business, 47, 137-149. 
Guender, Alfred and Sharon McCaw (2000). "The inflationary bias in a model of the open economy." Economics Letters, 68, 173-178.

Hau, Harald (2002). "Real Exchange Rate Volatility and Economic Openness: Theory and Evidence." Journal of Money, Credit and Banking, 34, 611-30.

Hendry, David and Jurgen Doornik (2001). "Empirical Econometric Modelling Using PcGIVE 10." London: Timberlake Consultants Press.

Jordan, Thomas (1997). "Disinflation costs, accelerating inflation gains, and central bank independence." Weltwirtschaftliches Archiv, 133, 1-21.

Karras, Georgios (1999). "Openness and the Effects of Monetary Policy." Journal of International Money and Finance, 18, 13-26.

Lane, Philip (1997). "Inflation in Open Economies." Journal of International Economics, $42,327-347$.

Lucas, R. (1973). "Some international evidence on output-inflation trade-offs." American Economic Review, 326-344.

McCarthy, J. (1999). "Pass-through of exchange rates and import prices to domestic inflation in some industrialised economies." BIS working paper no. 79 .

Muellbauer, John and Luca Nunziata (2004). "Forecasting (and Explaining) U.S. Business Cycles." Mimeo, Nuffield College.

Nelson, Edward (2003). "UK Monetary Policy 1972-97: A Guide Using Taylor Rules." In P. Mizen ed. Central Banking, Monetary Theory and Practice: Essays in honour of Charles Goodhart, pp. 195-216. Edward Elgar, Cheltenham UK.

Nielsen, Heino and Christopher Bowdler (2005). "Inflation Adjustment in the Open Economy: An I(2) Analysis of UK Prices." Empirical Economics, forthcoming.

Obstfeld, Maurice and Kenneth Rogoff (1996). Foundations of International Macroeconomics. MIT Press, Cambridge MA.

Pagan, Adrian (1984). "Econometric issues in the analysis of regressions with generated regressors." International Economic Review, 221-248.

Razin, Assaf and Chi-Wa Yuen (2002). "The 'New Keynesian' Phillips Curve: Closed Economy vs. Open Economy." Economics Letters, 75, 1-9. 
Reinhart, Carmen and Kenneth Rogoff (2004). "The Modern History of Exchange Rate Arrangements: A Reinterpretation." Quarterly Journal of Economics, 119, 1-48.

Rogoff, Kenneth (1985). "The Optimal Degree of Commitment to an Intermediate Monetary Target." Quarterly Journal of Economics, 100, 1169-1189.

Romer, David (1993). "Openness and Inflation: Theory and Evidence." Quarterly Journal of Economics, 108, 869-903.

Shambaugh, Jay (2004). "The effect of fixed exchange rates on monetary policy." Quarterly Journal of Economics, 108, 301-352.

Stock, James, Jonathan Wright and Motohiro Yogo (2002). "A Survey of Weak Instruments and Weak Identification in Generalized Method of Moments." Journal of Business and Economic Statistics, 518-529.

Temple, Jonathan (2002). "Openness, Inflation and the Phillips Curve: A Puzzle." Journal of Money, Credit and Banking, 34, 450-468.

Yuen, Chi-Wa (2001). "Openness and the Output-Inflation Tradeoff: Floating vs. Fixed Exchange Rates." International Economic Journal, 16, 1-26. 
Figure 1: Conditional effects on the slope of the Phillips curve
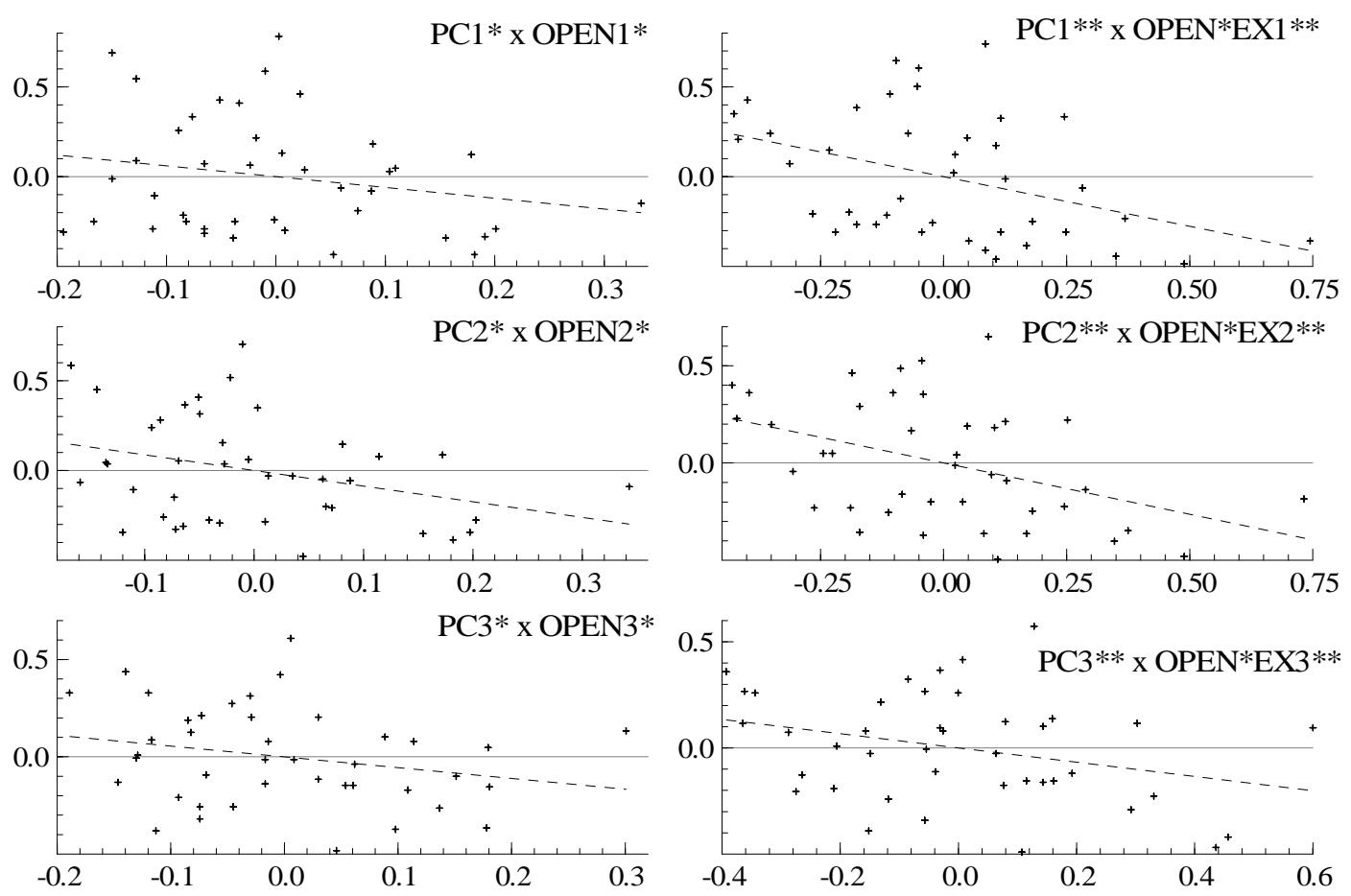

Notes: Rows 1, 2 and 3 correspond to partial regression lines from columns 6,8 and 10 respectively in Table 1 . See the text for further details. 


\begin{tabular}{|c|c|c|c|c|c|}
\hline \multicolumn{6}{|c|}{ Oppenness and the output-inflation trade-off } \\
\hline Regression & 1 & 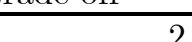 & 3 & 4 & 5 \\
\hline Observation period & $1948-86$ & $1948-86$ & $1973-86$ & $1973-86$ & $1981-98$ \\
\hline Constant & $0.56(4.81)$ & $0.57(4.25)$ & $0.34(2.50)$ & $0.37(2.68)$ & $0.25(1.99)$ \\
\hline OPEN & $0.08(0.36)$ & $0.08(0.39)$ & $-0.15(0.43)$ & $-0.28(0.81)$ & $0.20(0.59)$ \\
\hline OPEN*EX & & $0.03(0.22)$ & & $-0.22(2.13)$ & \\
\hline INF & $-5.56(3.19)$ & $-5.65(3.17)$ & & & \\
\hline SQINF & $8.37(2.76)$ & $8.59(2.72)$ & & & \\
\hline VOL & $1.01(0.39)$ & $0.97(0.36)$ & & & \\
\hline SQVOL & $-2.22(0.36)$ & $-2.28(0.37)$ & & & \\
\hline $\mathrm{R}^{2}$ & 0.4 & 0.4 & 0.003 & 0.04 & $\overline{0.01}$ \\
\hline Sample size & 41 & 41 & 38 & 38 & 41 \\
\hline$\overline{\text { Regression }}$ & 6 & $\overline{7}$ & 8 & $\overline{9}$ & 10 \\
\hline Observation period & $1981-98$ & $1981-98$ & 1981-98 & $1981-98$ & $1981-98$ \\
\hline Constant & $0.45(3.27)$ & $0.64(4.73)$ & $0.68(5.39)$ & $0.74(5.76)$ & $0.72(5.44)$ \\
\hline OPEN & $-0.60(1.59)$ & $-0.87(2.53)$ & $-0.55(1.58)$ & $-0.57(1.62)$ & $-0.51(1.43)$ \\
\hline OPEN*EX & $-0.55(4.18)$ & $-0.53(3.77)$ & $-0.34(2.00)$ & $-0.31(1.65)$ & $-0.29(1.61)$ \\
\hline INF & & $-0.52(2.91)$ & $-1.76(4.59)$ & $-2.97(4.26)$ & $-2.71(2.84)$ \\
\hline SQINF & & & $0.87(4.02)$ & $1.14(4.38)$ & $0.98(2.22)$ \\
\hline VOL & & & & $0.81(2.82)$ & $0.39(0.44)$ \\
\hline SQVOL & & & & & $0.30(0.58)$ \\
\hline $\mathrm{R}^{2}$ & 0.17 & 0.36 & 0.51 & 0.56 & 0.57 \\
\hline Sample size & 41 & 41 & 41 & 41 & 41 \\
\hline
\end{tabular}




\begin{tabular}{|c|c|c|c|}
\hline \multicolumn{4}{|l|}{ Table 2} \\
\hline \multicolumn{4}{|c|}{$\begin{array}{l}\text { Robustness checks for openness and the output-inflation trade-off } \\
\end{array}$} \\
\hline Robustness check & Sontrol for inflation and its square? & OPEN & $\mathrm{OPEN}^{*} \mathrm{EX}$ \\
\hline Exclude Israel & $\mathrm{NO}$ & $-0.64(1.40)$ & $-0.58(3.28)$ \\
\hline Exclude Israel & YES & $-0.82(2.36)$ & $-0.46(2.81)$ \\
\hline $\begin{array}{l}\text { Exclude Argentina, } \\
\text { Bolivia and Brazil }\end{array}$ & $\mathrm{NO}$ & $-0.89(2.36)$ & $-0.61(4.53)$ \\
\hline $\begin{array}{l}\text { Exclude Argentina, } \\
\text { Bolivia and Brazil }\end{array}$ & YES & $-0.41(1.49)$ & $-0.26(1.57)$ \\
\hline $\begin{array}{l}\text { Measure PC using } \\
\text { single EX regime }\end{array}$ & $\mathrm{NO}$ & $-1.12(2.30)$ & $-0.63(3.41)$ \\
\hline $\begin{array}{l}\text { Measure PC using } \\
\text { single EX regime }\end{array}$ & YES & $-1.28(2.51)$ & $-0.56(2.57)$ \\
\hline $\begin{array}{l}\text { Use Shambaugh } \\
\text { exchange rate indicators }\end{array}$ & NO & $-0.13(0.39)$ & $-0.75(2.57)$ \\
\hline $\begin{array}{l}\text { Use Shambaugh } \\
\text { exchange rate indicators }\end{array}$ & YES & $-0.19(0.80)$ & $-0.30(1.03)$ \\
\hline
\end{tabular}

Coefficient estimates (absolute heteroscedasticity consistent t-ratios) for versions of regression 6 in Table 1 modified according to the notes in the first column. 


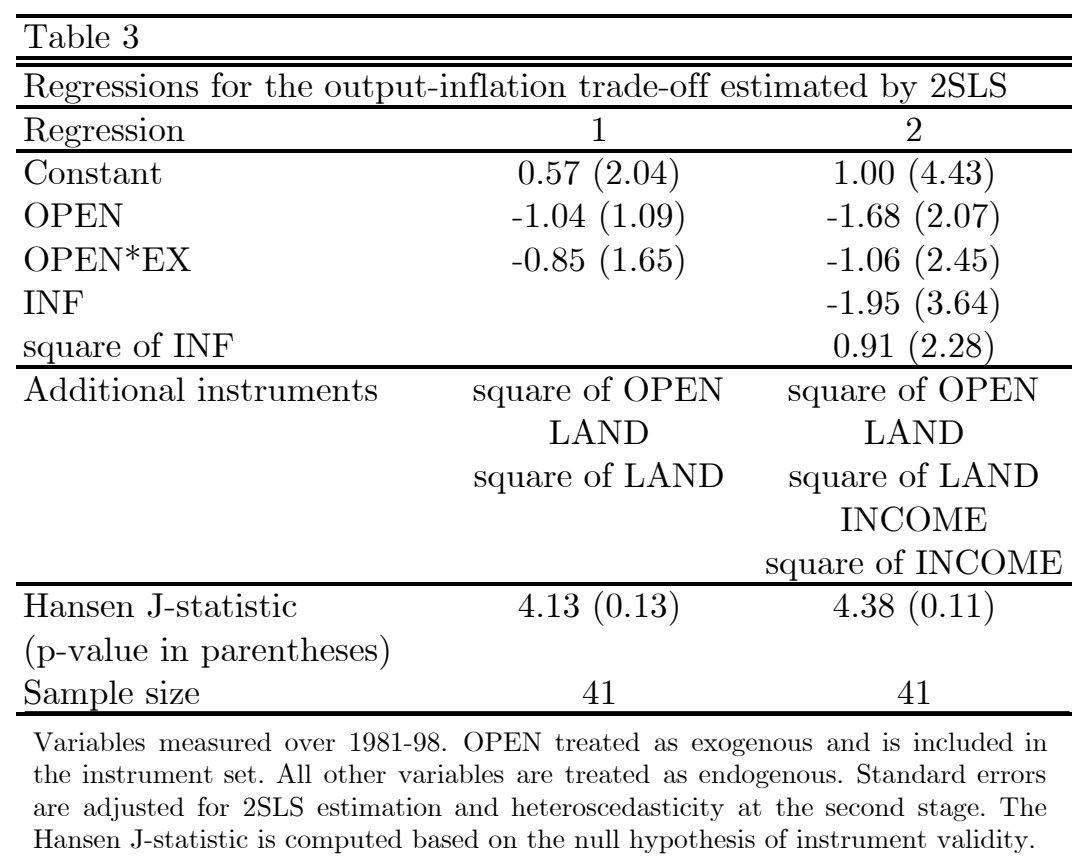




\begin{tabular}{|c|c|c|c|}
\hline \\
\hline \multicolumn{4}{|c|}{$\begin{array}{l}1 \text { able } 4 \\
\text { Openness and the sacrifice ratio } \\
\end{array}$} \\
\hline Regression & 1 & 2 & 3 \\
\hline Constant & $0.11(0.23)$ & $1.87(3.75)$ & $2.56(3.98)$ \\
\hline OPEN & $-0.55(0.42)$ & $-2.65(1.87)$ & $-5.31(2.89)$ \\
\hline OPEN*EX & $-0.08(0.12)$ & & $-1.65(2.38)$ \\
\hline LENGTH & $0.45(3.90)$ & & \\
\hline INFLOSS & $-0.18(2.58)$ & & \\
\hline PEAK & $0.05(1.32)$ & & \\
\hline $\mathrm{R}^{2}$ & 0.25 & 0.04 & 0.09 \\
\hline Sample size & 65 & 71 & 71 \\
\hline No. of countries & 19 & 38 & 38 \\
\hline Observation period & 1961-91 & $1981-98$ & $1981-98$ \\
\hline Regression & 4 & 5 & 6 \\
\hline Constant & $0.38(0.74)$ & $0.51(1.02)$ & $0.58(1.07)$ \\
\hline OPEN & $-4.31(2.86)$ & $-3.18(2.05)$ & $-3.19(2.04)$ \\
\hline OPEN*EX & $-0.88(1.75)$ & $-0.07(0.12)$ & $-0.05(0.07)$ \\
\hline LENGTH & $0.46(4.48)$ & $0.46(4.61)$ & $0.45(4.32)$ \\
\hline INFLOSS & & $-0.04(2.20)$ & $-0.03(1.36)$ \\
\hline PEAK & & & $-0.004(0.42)$ \\
\hline $\mathrm{R}^{2}$ & 0.34 & 0.37 & 0.37 \\
\hline Sample size & 71 & 71 & 71 \\
\hline No. of countries & 38 & 38 & 38 \\
\hline Observation period & $1981-98$ & $1981-98$ & $1981-98$ \\
\hline
\end{tabular}




\begin{tabular}{lccc}
\hline \multicolumn{1}{l}{ Table 5 } \\
\hline \hline Robustness checks for openness and the sacrifice ratio & & \\
\hline Dummy included for & Control for LENGTH, INFLOSS, PEAK? & \multicolumn{1}{c}{ OPEN } & OPEN*EX \\
\hline Finland, 1989-96 & NO & $-4.47(2.76)$ & $-1.31(2.15)$ \\
Finland, 1989-96 & YES & $-2.67(1.85)$ & $0.09(0.14)$ \\
Panama, 1980-86 & NO & $-4.46(2.55)$ & $-1.87(2.71)$ \\
Panama, 1980-86 & YES & $-2.45(1.61)$ & $-0.43(0.72)$ \\
\hline
\end{tabular}

Coefficient estimates (absolute heteroscedasticity-consistent t-ratios in parentheses) for regressions of the sacrifice ratio on OPEN and OPEN*EX. Dummy variables included for observations noted in first column, additional controls noted in second column. 
Table 6

\begin{tabular}{lcc}
\hline \hline \multicolumn{2}{l}{ Regressions for the sacrifice ratio estimated by 2SLS } & \\
\hline Regression & 1 & 2 \\
\hline Constant & $5.29(3.54)$ & $3.63(4.54)$ \\
OPEN & $-15.74(2.84)$ & $-9.38(3.54)$ \\
OPEN*EX & $-8.14(2.74)$ & $-4.19(2.69)$ \\
\hline Additional instruments & LAND & LAND \\
& square of LAND & square of LAND \\
& INCOME & INCOME \\
& square of INCOME & square of INCOME \\
& & square of OPEN \\
\hline Hansen J-statistic & $2.43(0.49)$ & $7.09(0.13)$ \\
(p-value in parentheses) & & 71 \\
Sample size & 71 & \\
\hline
\end{tabular}

OPEN is treated as exogenous and is included in the instruemnt set. EX is treated as endogenous. Standard errors are adjusted for 2SLS estimation and heteroscedasticity at the second stage. The Hansen J-statistic is computed based on the null hypothesis of instrument validity. 


\begin{tabular}{lrrrrr}
\hline Table 7 \\
\hline \hline Regressions for the sacrifice ratio with CBI controls & & & \\
\hline Regression & \multicolumn{1}{l}{ 1 } & 2 & 3 & 4 & 5 \\
\hline Constant & $3.61(2.45)$ & $4.38(2.54)$ & $0.92(0.68)$ & $0.94(0.69)$ & $1.01(0.73)$ \\
OPEN & $-5.98(1.56)$ & $-9.23(1.91)$ & $-7.66(1.75)$ & $-6.24(1.48)$ & $-6.27(1.47)$ \\
OPEN*EX & & $-1.80(1.71)$ & $-1.37(1.66)$ & $-0.65(0.67)$ & $-0.65(0.67)$ \\
LENGTH & & & $0.49(4.26)$ & $0.49(4.38)$ & $0.48(4.07)$ \\
INFLOSS & & & & $-0.03(1.45)$ & $-0.03(0.68)$ \\
PEAK & & & & & $-0.01(0.47)$ \\
CBI & $-4.28(1.09)$ & $-4.48(1.08)$ & $-1.30(0.36)$ & $-1.05(0.30)$ & $-1.01(0.28)$ \\
OPEN*CBI & $10.56(0.89)$ & $11.85(0.97)$ & $7.21(0.62)$ & $5.95(0.53)$ & $5.76(0.50)$ \\
\hline$R^{2}$ & 0.06 & 0.1 & 0.32 & 0.34 & 0.34 \\
Sample size & 53 & 53 & 53 & 53 & 53 \\
\hline
\end{tabular}

The CBI variable is the Cukierman (1992) index of the legal independence of central banks (LVAU). Absolute heteroscedasticity-consistent t-ratios in parentheses. 


\begin{tabular}{|c|c|c|c|c|c|}
\hline Table A1 & & & & & \\
\hline Measures of the & output-inflation t & deoff and the sa & rifice ratio & & \\
\hline Country & $\begin{array}{c}\text { Output-inflation } \\
\text { trade-off }\end{array}$ & $\begin{array}{l}\text { Sacrifice ratio } \\
\text { Disinflation } 1\end{array}$ & Disinflation 2 & Disinflation 3 & Disinflation 4 \\
\hline$\overline{\text { Argentina }}$ & -0.041 & & & & \\
\hline Australia & 0.613 & $1.092(82-84)$ & $0.013(86-88)$ & 1.651 (89-93) & \\
\hline Austria & 0.753 & $-0.695(81-83)$ & $0.344(84-87)$ & $3.521(92-98)$ & \\
\hline Belgium & 0.588 & $1.48(82-87)$ & $0.636(90-95)$ & & \\
\hline Bolivia & -0.006 & $0.478(91-94)$ & & & \\
\hline Brazil & -0.003 & & & & \\
\hline Canada & 0.764 & $1.601(81-85)$ & $3.223(90-94)$ & & \\
\hline Colombia & 0.157 & & & & \\
\hline Costa Rica & -0.113 & $0.006(82-85)$ & $-0.294(91-93)$ & & \\
\hline Denmark & 0.555 & $1.287(80-86)$ & $3.927(88-93)$ & & \\
\hline Dominican Rep & -0.163 & $0.334(80-82)$ & $-0.082(85-87)$ & $0.066(90-93)$ & 0.059 (95-97) \\
\hline Ecuador & 0.067 & $-0.074(83-85)$ & $0.027(89-91)$ & $-0.035(92-95)$ & \\
\hline El Salvador & 0.101 & $2.232(80-82)$ & $-0.145(86-88)$ & $0.297(90-91)$ & \\
\hline Finland & 0.687 & $0.812(81-87)$ & $10.529(89-96)$ & & \\
\hline France & 0.362 & $0.926(81-87)$ & $1.309(90-94)$ & & \\
\hline Germany & 0.629 & $2.132(80-86)$ & & & \\
\hline Greece & 0.109 & $1.536(80-84)$ & $0.568(86-88)$ & & \\
\hline Guatemala & -0.015 & $-0.375(80-82)$ & $0.019(86-88)$ & $-0.06(90-95)$ & \\
\hline Iceland & 0.074 & $0.818(88-95)$ & & & \\
\hline Iran & 0.31 & $-0.328(95-98)$ & & & \\
\hline Ireland & 0.537 & $1.454(81-88)$ & $-1.851(89-93)$ & & \\
\hline Israel & -0.007 & $-0.056(89-93)$ & & & \\
\hline Italy & 0.029 & $1.352(80-87)$ & $2.125(90-94)$ & $0.245(95-98)$ & \\
\hline Jamaica & 0.051 & $0.027(85-87)$ & & & \\
\hline Japan & 0.917 & $2.916(80-87)$ & $0.783(90-95)$ & & \\
\hline Mexico & -0.124 & $-0.246(83-85)$ & & & \\
\hline Netherlands & 0.586 & $1.443(81-87)$ & $3.922(91-96)$ & & \\
\hline New Zealand & 0.297 & $-0.191(80-84)$ & $-0.653(86-92)$ & & \\
\hline Nicaragua & 0.019 & & & & \\
\hline Norway & 0.255 & $1.164(81-85)$ & $4.122(87-94)$ & & \\
\hline Panama & 0.754 & $-2.323(80-86)$ & & & \\
\hline Peru & 0.029 & & & & \\
\hline Phillipines & -0.143 & $-0.165(80-82)$ & $0.376(84-86)$ & $1.038(91-94)$ & \\
\hline Portugal & 0.114 & $0.108(84-87)$ & & & \\
\hline Spain & 0.436 & $3.697(77-88)$ & $6.06(90-98)$ & & \\
\hline Sweden & 0.431 & $1.726(80-87)$ & $0.569(90-98)$ & & \\
\hline Switzerland & 0.922 & $0.492(82-87)$ & $2.716(91-98)$ & & \\
\hline Tunisia & 0.551 & $-1.497(91-93)$ & & & \\
\hline UK & 1.039 & $2.363(80-87)$ & $1.54(90-93)$ & & \\
\hline US & 0.771 & $1.303(80-86)$ & $2.485(90-94)$ & & \\
\hline Venezuela & -0.09 & $-0.414(80-83)$ & $-0.38(89-92)$ & & \\
\hline
\end{tabular}

